Bibliography of Creative African Writing

A Preliminary bibliography of creative African writing in the European languages has been compiled by Mrs. Margaret Amosu, Librarian of the Institute of African Studies, and Sub-librarian, Africana Department, University of Ibadan, as a special supplement to African Notes. Approximately 250 authors and 650 titles are included, arranged in alphabetical order by countries. Writers born on the African continent or on one of the islands considered part of it qualify for inclusion. Works in indigenous languages have been omitted because of the difficulty of producing a comprehensive bibliography of such works without very detailed and costly research, though the Institute is aware of the urgent need for such a compilation and hopes to tackle it later. The present bibliography is intended as a preliminary step towards a much larger and more reliable work. It is requested that any omissions and errors noticed should be reported to the compiler, Mrs. Margaret Amosu, c/o Institute of African Studies, University of Ibadan.

\title{
International Seminar on Social Class and Elites in Contemporary Africa
}

THE Sixth of the Institute's series of International African Seminars, organized with the aid of a grant made by the Ford Foundation, was held in the University of Ibadan in July of last year. The meetings were organized by Dr. Peter C. Lloyd, Acting Head of the Department of Sociology in the University. The Seminar was attended by eighteen specialist participants-social anthropologists, sociologists, and social psychologists-each with considerable experience in one or more African territories. A very wide range of African societies was thus represented. A small number of observers were present at the sessions.

The participants had prepared in advance a series of papers presenting some aspect of their own research and these formed the background for discussion in the sessions of the Seminar. The first two meetings were devoted to descriptions of the composition and historical development of the elite in various African territories. On the third day the educational systems of these states were discussed, with reference to patterns of social mobility among the newly educated. Subsequent sessions were devoted to the family structure of elite families, the participation of their members in traditionalist and modern associations, and the concepts of achievement and prestige ranking held by them. Throughout this period the participants had consented to use the term 'elite' loosely, to embrace the relatively well educated and wealthy members of the societies described. In the two final sessions they discussed the concepts of elite and social class with special reference to the applicability of these terms to the African data which had been presented.

The daily sessions continually emphasized the lack of precise data on many of the topics under discussion and participants relied heavily on their own intuitive experiences. The success of the seminar will be measured by the research it provokes into the unexplored areas. The papers presented, together with an introduction substantially summarizing the discussions at the Seminar sessions, are being prepared for early publication.

\section{International Economics Seminar at the University of Edinburgh}

A THReE-DAY seminar on 'African Primary Production and International Trade' was held from 20 to 23 September I 964 under the auspices of the university's Department of Political Economy and Centre of African Studies. The seminar was organized by Mr. Ian G. Stewart, Reader in Economics and Vice-Convener of the Centre of African Studies Committee, and was attended by some forty African, American, and British economists concerned with trade and development prospects for African primary commodities. Included among the invited participants were academic and government economists from Ghana, Nigeria, 
the Sudan, and East Africa, as well as from the U.N. Economic Commission for Africa and research centres in Britain and the U.S.A.

The work of the seminar hinged upon thirteen papers which were contributed as follows : 'External Trade, Capital Distortion and Planned Development' by O. Aboyade, Lecturer in Economics, University of Ibadan; 'Prospects for African Exports of Agricultural Products' by J. A. C. Brown, Cambridge Department of Applied Economics and Professorelect of Econometrics, University of Bristol; ' Planning the Development of Peasant Agriculture' by E. S. Clayton, Lecturer in Agricultural Economics, Wye College, London; 'Peasant Agriculture, Development and Export Instability : the Nigerian Case' by G. K. Helleiner, Assistant Professor of Economics, Yale University; "The Marketing of Crops in Uganda and Tanganyika' by I. Livingstone, Lecturer in Economics, Sheffield University; ' Development of African Production and International Trade in Timber' by J. J. MacGregor, Senior Lecturer in Forest Economics, Commonwealth Forestry Institute, Oxford; 'The Role of International Organizations in Developing African Primary Products' by H. M. A. Onitiri, Director, Nigerian Institute of Social and Economic Research, Ibadan; 'Agricultural Commodity Projections, Real Growth and the Gains from Trade ' by H. W. Ord, Lecturer in Economics, University of Edinburgh; 'The Coffee Industries of East Africa in the World Market Setting' by J. W. F. Rowe, Fellow of Pembroke College, Cambridge; 'International Trade and Development-the Special Interests of Africa' by D. G. M. Seers, Director, Economic Development Division, U.N. Economic Commission for Africa; 'The Determinants of Cocoa Supply in West Africa' by R. M. Stern, Associate Professor, University of Michigan; 'Stabilization Policies for Cotton in the Sudan' by A. A. Suliman, University of Khartoum; 'West African Demand Functions' by W. D. C. Wright, Assistant Lecturer, Department of Political Economy, University of Edinburgh. Other participants who offered prepared comments were Messrs. E. Bennathan (Birmingham), R. Galletti (London), A. M. M. MacFarquhar (Cambridge), J. E. A. Manu (Ghana), J. H. Mensah (Ghana Planning Commission), P. Ndegwa (Makerere), C. J. Taylor (Edinburgh), and R. L. West (Rockefeller Foundation, New York).

Arrangements are being made to publish the proceedings of the Seminar in two parts. The papers will be available shortly in book form, to be published by Edinburgh University Press. It is also hoped to make available in typescript a record of invited comment and a proportion of the discussion.

\section{'La structure de la parenté chez les Goula Iro'}

Dans l'article de Claude A. Pairault sur la structure de la parenté chez les Goula Iro (Africa, October 1964, p. 360-369), une erreur typographique a masqué la différence notée par l'auteur entre nò-mènèe á ('mon germain féminin, c'est-à-dire 'ma scur'), appellation employée par Ego masculin, et nò-mènèè-á ('mon germain de même sexe'), appellation employée par Ego masculin pour nommer son 'frère' et par Ego féminin pour nommer sa 'sœur'.

Le lecteur est donc prié de rectifier en conséquence le texte imprimé p. 36 I (ligne 22) et p. 367 (lignes 18 et 30 ). 